\title{
Conservation Value of Forest Plantations: A Study of Four Timber Species in Sri Lanka
}

\author{
M. R. Wijesinghe ${ }^{* 1}$ and V. R.de Silva ${ }^{1}$ \\ ${ }^{1}$ Department of Zoology, University of Colombo, Colombo 03, Sri Lanka \\ Date Received: 23-10-2011～Date Accepted: 16-02-2012
}

\begin{abstract}
This paper assesses the potential of forest plantations in Sri Lanka consisting of teak, mahogany and two species of eucalyptus, to facilitate the conservation of biodiversity using two taxonomic groups, the plants and birds. Their diversity in plantations at a harvestable age were compared with that of a natural forest. Enumerations of plants and dbh/height measurements were conducted in quadrates, while avifauna was recorded along transects. Results show that plantation forests supported a reasonably rich community of both plants and birds, including natives and endemics. A large proportion of species were common to both plantations and natural forests indicating that plantations hold a subset of forest species. The presence of plants of various height and girth classes together with the high diversity and evenness values indicate that, although timber plantations are initially established as mono-cultivations, they facilitate the colonization of additional species. These findings thus demonstrate that forest plantations could make a significant contribution towards biodiversity conservation.
\end{abstract}

Key words: Biodiversity, birds, forestry, conservation value, timber plantations

\section{Introduction}

Timber is one of the most important raw materials extracted from natural forests. The expansion of the human population and the resultant increase in the demand for this commodity has led to the destruction of large extents of natural forests in many parts of the world. The concept of forest plantations primarily evolved to meet the growing demand for timber. Worldwide, forest plantations cover less than five percent of the land area (about 187 million ha), but are able to meet 20 percent of the wood demand (Larsen, 2002). In addition to playing an important role in meeting the global timber needs, and also to some extent the demand for fuel wood, forest plantations offer a wide range of other benefits. Plantations are ideal for sequestering carbon and hence could make a significant contribution towards mitigating adverse effects of global climate change (Sedjo, 2001; Stavins and Richards, 2005). These man-made forests have been also used to stabilize fragile ecosystems such as sand dunes, and also for improving water quality and providing shelter for livestock (Gunatilleke and Gunatilleke, 1983; Rosomon, 1994; FAO, 2009). It is also becoming increasingly apparent that forest plantations have a high conservation value. Forest plantations because they provide refuges for indigenous biotic elements, are frequently used to compensate for the loss of natural forests in both tropical and temperate countries (e.g. Sample, 2003; Barlow et al., 2007; Butler, 2007, Cartledge, 2008).

Correspondence: mayuri@zoology.cmb.ac.lk

Tel: +9471446277

ISSN 2235-9370 Print / ISSN 2235-9362 Online (C2012 University of Sri Jayewardenepura 
Sri Lanka is a tropical island nation endowed with natural forests rich in biodiversity. Nevertheless, over the past few decades, trends in population expansion and economic development in the country have led to immense deforestation with the natural forest cover of 70 percent in 1900 having dwindled to less than 24 percent by 1992 (Mahindapala, 2001). The remnant forests are severely fragmented and are threatened by encroachment and overuse (Marambe et al., 2006). Forest plantations in Sri Lanka were established in the 1870s, and at present cover nearly 93000 ha and consist mainly of teak (Tectona grandis), mahogany (Swietenia macrophylla) and Eucalyptus species (Forest Department, 1999). Since deforestation is one of the major causes of biodiversity loss in Sri Lanka (Mahindapala, 2001), and since studies elsewhere have shown that forest plantations could support biodiversity, the present study attempted to assess the conservation value of these timber plantations.

\section{Methodology}

\subsection{The study species}

The four selected timber species, namely teak (Tectona grandis), mahogany (Swietenia macrophylla), Eucalyptus microcorys and Eucalyptus grandis are well established as plantation timber species in Sri Lanka. These species fetch a high economic value and are in high demand both in local and export markets. Teak was first introduced to the country from the Malabar Coast in 1680 as a species of commercial importance (Forest Department, 1997). It is one of the outstanding timber species in the world on account of its valuable properties, notably durability, strength, moderate weight, stability and relative ease with which it can be processed. In Sri Lanka it is grown extensively in both the dry and intermediate zones. Mahogany was planted under the protective cover of an already established plantation or under natural forests (Thayaparan, 2000). Its wood is used for decorative purposes and is grown in the intermediate and wet zones of Sri Lanka. Eucalyptus was among the first three exotics to be introduced to Sri Lanka to be raised as a forest plantation species. In Sri Lanka there are currently over 30,000 ha of eucalyptus plantations. Its wood was found to be very promising for use as railway sleepers and as industrial timber. Both E. microcorys and E. grandis thrive in the hill country.

\subsection{Biodiversity assessments}

The present study was conducted in 2008-2009. Three plantations over 10 ha in extent were selected for each of the four timber species from the two districts Kurunegala and Nuwara-Eliya in Sri Lanka, in which these species are commonly grown. These plantations had been originally established as monocultures and are managed by the Forest Department of Sri Lanka. All plantations selected for the study were of a harvestable age i.e. teak 30 years, mahogany 40 years and the two Ecucalyptus spp. 25 years. Four natural forests, one each for the four timber species, that was state protected and in close proximity to the timber plantations, was selected as the control site for comparing biodiversity. These natural forests are Kandapola and Ohiya in the Nuwara Eliya district and Maragala kanda and Galagedara in the Kurunegala district. In each of the plantations vegetation surveys were conducted in five $10 \times 10 \mathrm{~m}$ quadrates ( $\mathrm{n}=15$ per timber species), randomly placed within the plantations but separated by a distance of at least $50 \mathrm{~m}$. All individuals (other than those with dbh below $5 \mathrm{~cm}$ ) were enumerated, and the dbh and height recorded. Five quadrates each were surveyed in the four natural forests.

Birds have been often used as indicators of human disturbance and habitat suitability (Canterbury et al,. 2000; Francl and Schnel, 2002). Thus in the present study birds were selected as the indicator group to assess the conservation value of the forest plantations for fauna. Recording of avifauna was conducted along transects placed in the vicinity of the vegetation enumeration quadrates. Five $200 \mathrm{~m}$ transects ( $\mathrm{n}=15$ per timber species) were marked and birds observed or heard at $10 \mathrm{~m}$ intervals along transects were recorded. At each point recording was conducted for 10 minutes. Transects were walked on two days and twice a day i.e. between 0630 and $0930 \mathrm{hrs}$ and between 1500 and 1800 hrs. Five transects were also surveyed in each of the natural forests. 
For both plants and birds, species lists were constructed and the Shannon Weiner Diversity indices $H^{\prime}=-\sum$ pi.log pi where pi is the proportional abundance of each species were calculated separately for both plantations and the adjacent natural forests. Evenness values $\left(\mathrm{J}^{\prime}=\mathrm{H}^{\prime} / \mathrm{H}\right)$ where $\mathrm{H}=$ $\log \mathrm{S}$ and $\mathrm{S}$ is the number of species found in the plantation/forest was also calculated.

\section{Results}

Overall, the results of the present study revealed that the plantation forests of all four timber species supported a considerable number of species of both plants and birds, although lower than that observed in the adjacent natural forests. Considering plant species, the plantations on average supported half the number of species as the respective natural forests. The plant species in the plantations contained trees and herbaceous species. Another noteworthy fact with regard to floristic composition is that plantation forests also supported a high number of endemic species (Table 1). The endemics recorded in the plantations are given in Appendix 1. In the case of teak, mahogany and E. grandis, over 90 per cent of the endemics recorded in natural forests were also recorded in plantations. With the exception of mahogany, all species recorded in plantations were also recorded in the natural forest. Trends in abundance show that the mean abundance of plants in the four natural forests was approximately two to three folds higher than that in plantations (Table 1). Nevertheless it is apparent that plantations support a large density of plants which contained saplings of tree species. Despite the differences in species richness and abundance in flora between natural forests and forest plantations striking differences were not evident with respect to diversity. Apart from E. grandis where the most pronounced difference in diversity was evident, the diversity in other plantations was remarkably high (over 0.90). This together with the high evenness values for all timber species reveals uniform distribution with low numbers of dominant species indicating that these plantations harbour a rich community of other types of floral species in addition to the artificially established timber species.

Table 1: Species richness, abundance and the Shannon-Weiner Diversity Indices and Evenness values (mean + standard errors) for flora of plantations containing the four selected timber species (PL) and for adjacent natural forests (NF).

\begin{tabular}{|c|c|c|c|c|c|c|}
\hline & & $\begin{array}{r}\text { No. of } \\
\text { transects }\end{array}$ & Teak & Mahogony & E. microcorys & E. grandis \\
\hline \multirow[t]{2}{*}{ Total Species Richness } & PL & 15 & 20 & 34 & 10 & 15 \\
\hline & NF & 5 & 32 & 50 & 33 & 23 \\
\hline \multicolumn{3}{|c|}{ Proportion of species shared with natural forest } & $100 \%$ & $38.2 \%$ & $100 \%$ & $100 \%$ \\
\hline \multirow[t]{2}{*}{ Total No. of Endemics } & PL & 15 & 7 & 13 & 9 & $\overline{9}$ \\
\hline & NF & 5 & 9 & 13 & 17 & 11 \\
\hline \multirow{2}{*}{$\begin{array}{l}\text { Mean abundance (per } \\
\text { transect) }\end{array}$} & $\mathrm{PL}$ & 15 & $38.00 \pm 1.79$ & $62.27 \pm 3.80$ & $20.47 \pm 1.82$ & $25.67 \pm 3.00$ \\
\hline & NF & 5 & $90.80 \pm 6.42$ & $111.4 \pm 7.10$ & $69.00 \pm 3.62$ & $61.00 \pm 3.97$ \\
\hline \multirow{2}{*}{$\begin{array}{l}\text { Shannon Wiener } \\
\text { Diversity Index }\end{array}$} & $\mathrm{PL}^{*}$ & 15 & $1.07 \pm 0.12$ & $1.29 \pm 0.02$ & $0.91 \pm$ & $0.56 \pm 0.05$ \\
\hline & NF & 5 & 1.28 & 1.68 & 1.52 & 1.36 \\
\hline \multirow[t]{2}{*}{ Evenness } & $\mathrm{PL}^{*}$ & 15 & $0.86 \pm 0.04$ & $0.89 \pm 0.02$ & $0.97 \pm 0.01$ & $0.54 \pm 0.07$ \\
\hline & $\mathrm{NF}$ & 5 & 0.83 & 0.99 & 0.99 & 0.94 \\
\hline
\end{tabular}

* Mean for three plantations 
Figures 1 and 2 show the structure of plantations and natural forests in terms of height and dbh of the trees within the enumerated quadrats. Significant differences in abundance between plantations and natural forests were evident in some height or girth classes (t-Tests; $\mathrm{P}<0.05$ ). Nonetheless, it is clear that the overall pattern of distribution of plants in different height and girth classes in the plantation and natural forests are near similar. This is particularly evident in the case of both teak and mahogany where the lower height and dbh classes contain a relatively high numbers of individuals.
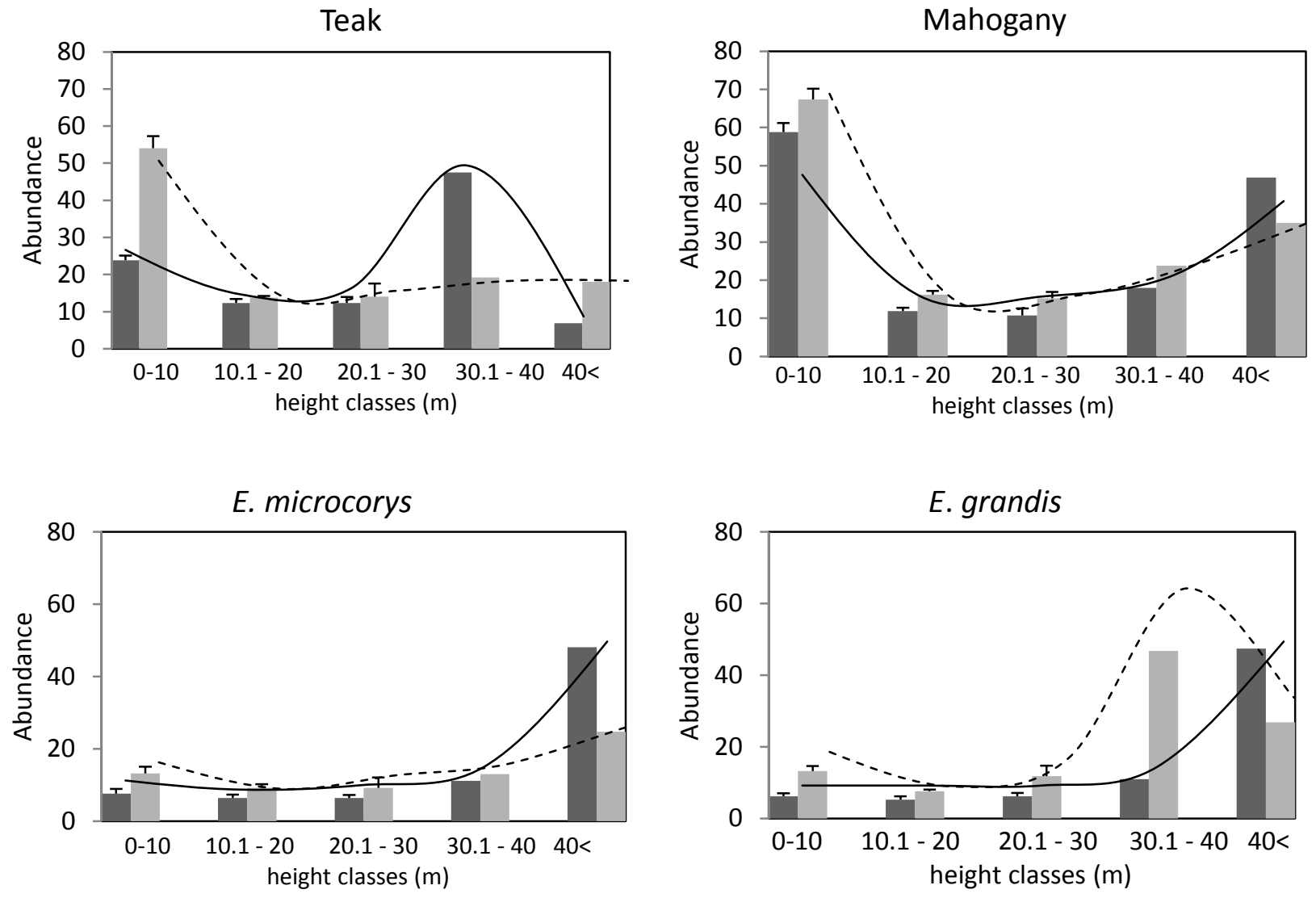

Figure 1: Mean abundance of plants (+ std. error) in each height class in both timber plantations (black) and adjacent natural forests (grey).

Similar trends were evident with avifauna. The species richness of birds was higher in natural forests than that of plantations but the magnitude of this disparity was much lower than that observed for flora (Table 2). For instance, the number of bird species in teak, mahogany and E. microcorys plantations were over half of that recorded from natural forests. With the exception of E. grandis where only $50 \%$ of the bird species was shared with the natural forests, all species in the other three timber plantations was also recorded from the natural forest. In comparison to plants, both natural forests and plantations supported a sparse community of endemics with most of the species recorded in forests being also present in plantations. As with species richness, the abundance of birds was higher in natural forests than in plantations but the difference in abundance was of a lower magnitude as that observed for plants. The diversity and evenness of birds in plantations were comparable to that in natural forests indicting that the species found were relatively evenly distributed in both habitats. The endemics recorded in the plantations are given in Appendix 2. 

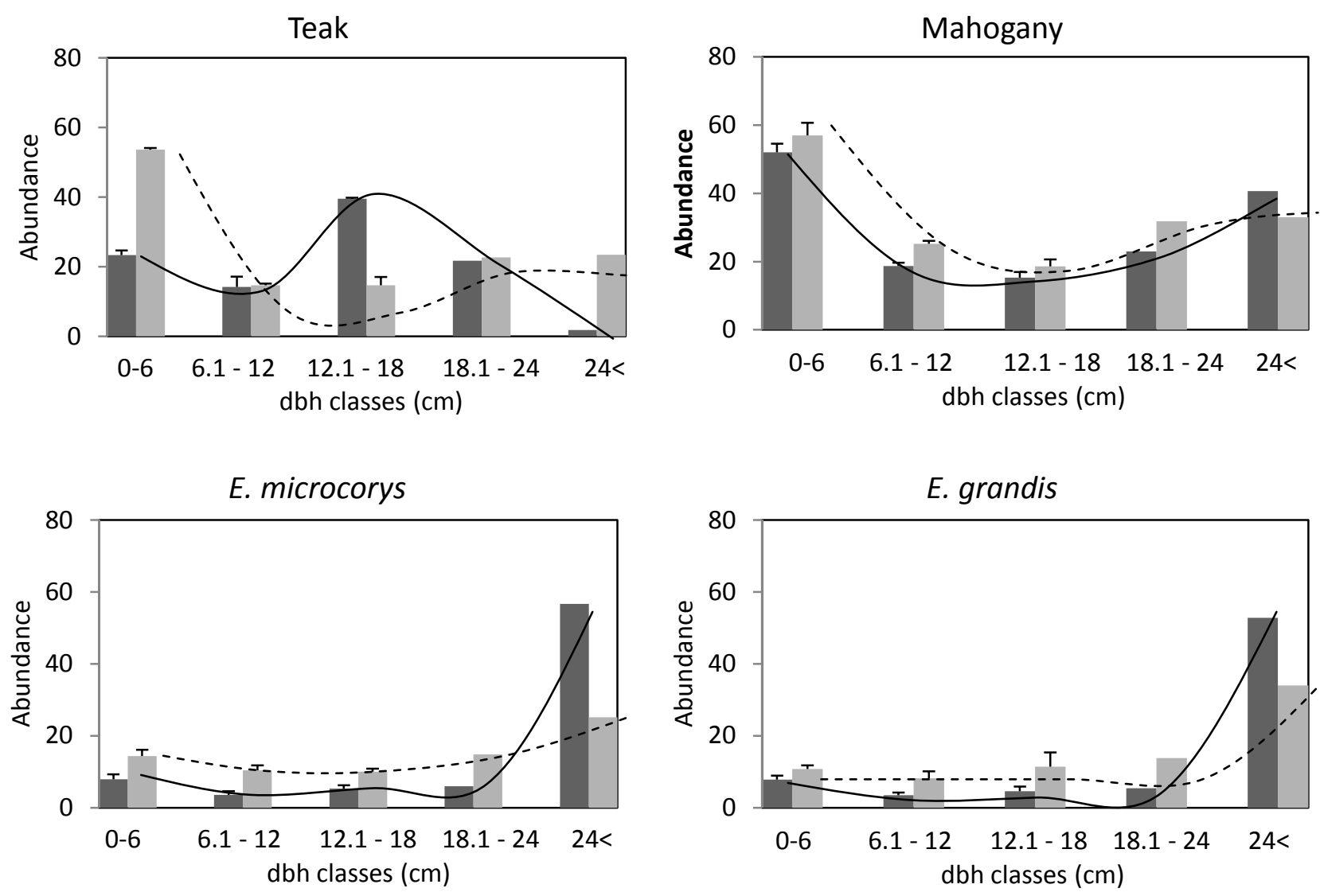

Figure 2: Mean abundance of plants (+ std. error) in each dbh class in both timber plantations (black) and adjacent natural forests (grey).

\section{Discussion}

The objective of this investigation was to assess the capacity of forest plantations containing four of the commonly grown timber species in Sri Lanka to facilitate the protection of the country's biodiversity. With respect to the two taxonomic groups under consideration, i.e. plants and birds, the results of the present study indicate that forest plantations have a reasonably high conservation value supporting the claim that these anthropogenic habitats in addition to its main role as a timber source, has the potential to function as a refuge for biodiversity.

The overall species richness and abundance of plants were lower in forest plantations than in the adjacent natural forests. This is to be expected since the plantations in comparison to natural forests are relatively young anthropogenic ecosystems, and are initially established as monocultures. This observation is consistent with those of other studies (Singhakumara, 1995; Yaron, 1998; Rhett, 2007). Nevertheless, the present study shows that anthropogenic forests could also support a relatively rich community of forest plants and birds. For instance, all bird species recorded in teak, mahogany and $E$. microcorys as well as a significant proportion of those in E. grandis, were shared with the respective natural forest. A similar trend was noted for the plants suggesting that plantations supported a subset of forest flora and fauna. Furthermore, the anthropogenic habitats supported many endemic plants and some endemic birds enhancing their potential to act as refuges of biodiversity. With regard to plants, the fact that plantations supported species of plants of different height and girth is also noteworthy. These findings are especially significant given that these anthropogenic habitats are originally established as even-aged monocultivations, consisting plants of similar height and girth. The diversity of flora, to a 
large extent, governs the richness of faunal species (Martin, 2001). The higher diversity of plant species in natural forests creates greater habitat heterogeneity in turn supporting a richer faunal community (Ball et al., 1994). Consequently, plantations in general supported a relatively lower diversity of plants and birds in comparison to the natural forests. Similar observations have been noted by others (E.g. Hartley, 2002; Lindenmayer and Hobbs, 2004).

Table 2: Species richness, Shannon-Weiner Diversity Indices and Evenness values (mean+standard errors) for birds in plantations containing the four selected timber species (PL) and for adjacent natural forests (NF).

\begin{tabular}{|c|c|c|c|c|c|c|c|}
\hline \multirow{3}{*}{$\begin{array}{l} \\
\text { Total Species } \\
\text { Richness }\end{array}$} & \multicolumn{2}{|c|}{$\begin{array}{l}\text { No. of } \\
\text { transects }\end{array}$} & \multirow{2}{*}{\multicolumn{2}{|c|}{$\begin{array}{r}\text { Teak } \\
7\end{array}$}} & \multirow{2}{*}{$\begin{array}{r}\text { Mahogony } \\
18\end{array}$} & \multirow{2}{*}{$\begin{array}{r}\text { E. microcorys } \\
6\end{array}$} & \multirow{2}{*}{$\begin{array}{r}\text { E. grandis } \\
10\end{array}$} \\
\hline & PL & 15 & & & & & \\
\hline & NF & 5 & & 11 & 23 & 15 & 18 \\
\hline \multicolumn{4}{|c|}{ Proportion of species shared with natural forest } & $100 \%$ & $100 \%$ & $100 \%$ & $50 \%$ \\
\hline \multirow{2}{*}{$\begin{array}{l}\text { Total No. of } \\
\text { Endemics }\end{array}$} & PL & 15 & & 1 & & 2 & 2 \\
\hline & NF & 5 & & 1 & - & 4 & 4 \\
\hline \multirow{2}{*}{$\begin{array}{l}\text { Abundance } \\
\text { (mean per } \\
\text { transect) }\end{array}$} & PL & 15 & & $.8 \pm 1.5$ & $22.53 \pm 1.78$ & $11.47 \pm 1.21$ & $10.33 \pm 1.13$ \\
\hline & NF & 5 & & $2+0.56$ & $30.40 \pm 3.64$ & $17.60+1.50$ & $19.8+2.35$ \\
\hline \multirow{2}{*}{$\begin{array}{l}\text { Shannon Wiener } \\
\text { Diversity Index }\end{array}$} & PL* & 15 & & $1 \pm 0.02$ & $0.99 \pm 0.09$ & $0.73 \pm 0.06$ & $0.81 \pm 0.05$ \\
\hline & NF & 5 & & 1.12 & 1.27 & 1.01 & 1.06 \\
\hline \multirow[t]{2}{*}{ Evenness } & PL* & 15 & & $3 \pm 0.05$ & $0.82 \pm 0.79$ & $0.92 \pm 0.01$ & $0.92 \pm 0.01$ \\
\hline & NF & 5 & & 0.93 & 0.93 & 0.93 & 0.92 \\
\hline
\end{tabular}

* Mean for three plantations

Comparing the four timber species with respect to overall richness and abundance of flora, it is apparent that plantations containing eucalyptus species supported a relatively poor community of plants than teak and mahogany. Binkly and Stape (2004) noting similar trends attribute this species impoverishment to the rapid uptake of nutrients and water which prevents other species from becoming established. It is also said that the leaves of eucalyptus degrade slowly resulting in a lower amount of nutrients returning to the soil in the form of humus (Wilson, 1992; Martin, 2001). Additionally, FAO (1998) reports that eucalyptus has a visible and scientifically established allopathic effect on other plants due to the emission of toxic compounds. As with the plants, the eucalyptus plantations in comparison to mahogany and teak also harboured a lower abundance of bird species. Bass et al. (1999) has documented that the abundance and diversity of mammals, birds and insects are considerably less in eucalyptus plantations. In addition to the loss of habitat heterogeneity, eucalyptus trees are not conducive for nesting birds because of the oily smell of the leaves (Roberts, 2002).

The extent to which forests plantations may contribute towards biodiversity conservation will depend, however, on how plantations are managed. Frequent disturbance caused by short rotation, clear felling and herbicide spraying are reported to be detrimental to the biota inhabiting forest plantations (Rosoman, 1994). Adopting suitable silvicultural measures would not only accelerate the establishment of species of both flora and fauna but also mitigate other adverse environmental impacts such as soil erosion and nutrient depletion (Gunatilleke and Gunatilleke, 1990). Plantations if established in grasslands or croplands, or in severely degraded areas will facilitate the colonization of additional species since planting of trees tend to increase the vertical complexity of the landscape. Forest 
plantations established in close proximity to natural forests would particularly enhance biodiversity (Toma, 2004; Kanowski, 2005). Colonization of additional plants or animals could be also accelerated if indigenous tree species are grown intermixed with timber crops (Webb et al., 1984). It has been reported that such measures would also increase the productivity of the plantations (Bandarathilake, 1999).

\section{Conclusion}

The results of the present study emphasize the fact that forest plantations have the potential to function as a refuge for wild species. This is particularly so with teak and mahogany plantations than with the eucalyptus plantations which supported lesser numbers of both plants and birds. This is especially relevant for Sri Lanka, a small tropical island where a large proportion of its rich biodiversity is threatened as a result of the destruction and fragmentation of its natural forests. Today many of the country's natural forests exist as isolated fragments. Forest plantations may be of special significance in such fragmented landscapes, since they could serve as potential habitat corridors that form critical links between isolated forest fragments (Mackinnon et al., 1986). The role of these man-made ecosystems in biodiversity conservation should therefore not be overlooked.

\section{References}

Ball, J.B., Hirai, S. Pandey, D. 1994. Commercial environmental forestry integrating trees into landscapes for multiple benefits. Forestry management 11:16-20

Bandaratillake, H. M. 1999. Administration report of the Conservation of Forests Sri Lanka for the year 1999. Forest Department. Sri Lanka.

Barlow, J. Gardner, T. A., Araujo, I. S. 2007. Quantifying the biodiversity value of tropical primary, secondary, and plantation forests Proceedings of the National Academic of Sciences of the United States of America 104 (47): 18555-18560.

Bass, S., Higman, S., Judd, N., Mayers, J. Nussbaum, R. 1999. The sustainable forestry hand book. Earthscan publications Ltd, London.191pp.

Binkley, D. and Stape, J.S. 2004. Beagle bay big tree country tropical timber plantation project fauna assessment survey. Ecologia general, 21:35-42

Canterbury, G. E., Martin, M. E., Petit, D. R., Petit, L. J.,Bradford, D. F. 2000. Bird Communities and Habitat as Ecological Indicators of Forest Condition in Regional Monitoring, Conservation Biology, 14 ( 2): 544-558.

Cartledge, S. 2008. Saving Biodiversity in Sarawak: Tree Plantations to Protect Borneo's Endangered Environment,http://reforestation.suite101.com/article.cfm/saving_biodiversity_in_sarawak\#ixzz0qW TU0Rht

FAO 1998. Report submitted to the regional expert consultation on Eucalyptus. FAO Sri Lanka, Colombo. 277pp.

FAO 2009. State of the world's forests, FAO Sri Lanka. Colombo.

Francl, K. E., Schnell, G. D. 2002. Relationships of Human Disturbance, Bird Communities, and Plant Communities Along the Land-Water Interface of a Large Reservoir Environmental Monitoring and Assessment 73 (1): 67-93.

Forest Department. 1997. The teak management plan, Vol 1. Ministry of Agriculture land and Forestry and the Forest Department, Battaramulla. 76pp.

Forest Department 1999. Designing an optimum protected area system for Sri Lanka's natural forests.. Volume 1. Forest Department of Sri Lanka, Battaramulla.

Gunatilleke, I.A.U.N., Gunatilleke , C.V.S 1983. Conservation of natural forests in Sri Lanka, The Sri Lanka forester, 16:40-45 
Gunatilleke, I.A.U.N. and Gunatilleke , C.V.S .1990. Distribution of Floristic Richness and its Conservation in Sri Lanka, Conservation Biology, 4:25

Hartley, M. J. 2002. Rationale and methods for conserving biodiversity in plantation forests, Forest Ecology and Management, 155: 81-95.

Kanowski, , J., Catterall, C. P. Wardell, J. G. W. 2005. Consequences of broadscale timber plantations for biodiversity in cleared rainforest landscapes of tropical and subtropical Australia. Forest Ecology and Management, 208 (359-372)

Larsen, J. 2002. Forest cover shrinking (online). http://www.global forest watch.org.

Lindenmayer, D. B., Hobbs, R. J. 2004. Fauna conservation in Australian plantation forests - a review. Biological Conservation 119, 151-168

Mackinnon, J., Mackinnon, C., Child, G., Thorsell, J. 1986. Managing Protected Areas in the Tropics. IUCN, Gland Switzerland.

Mahindapala, R. 2001. Biodiversity Planning on Asia. Chapter 17: Sri Lanka.

Marambe, B., Pushpakumara, D. K. N. G., Silva, P., Rathnayake, H. B., Vidanage, S. 2006. Chapter report on Impacts on Biodiversity. The Biodiversity Secretariate, Ministry of Environment. Colombo. 26 pp.

Martin, B. (2001) Eucalyptus plantations; research, management and development. World scientific publishing Co. Pvt Ltd.

Rhett A. B. 2007. In the Amazon, primary forest biodiversity tops that of secondary forest, plantations. http://news.mongabay.com/2007/1111-amazon.html.

Roberts, N. 2002. Prospects for Australian plantations: Business perspectives. Proceedings of the Conference in Australia.

Rosoman, G. 1994. The plantation effect: An ecoforestry review of the environmental effects of exotic monoculture tree plantations in Aotearoa, New Zealand. Sustainable forestry, 2: 323-343.

Sample, V. A. 2003. Forest plantations as components in a global biodiversity conservation strategy: The role of developed, temperate-forest countries. XII World Forestry Congress.

Sedjo, R.A. 2001. Forest carbon sequestration: Some issues for forest investments. Resources for the future, 25: 1 - 26.

Singhakumara, B.M.P. 1995. Floristic survey in Adam's Peak Wilderness. Sri Lanka Forest Department of Sri Lanka, Battaramulla. 156pp.

Stavins R. N., Richards, K. R. 2005. The cost of U.S. Forest-based carbpn sequestration. Pew Centre for Clobal Climate Change, Arlington. P. 52.

Thayaparan, S. 2000. Management plan for mahogany mixed plantations in Kegalle and Kurunegala division of Sri Lanka, Volume II. Forest inventory and management division, Forest Department of Sri Lanka, Battaramulla. 112pp.

Toma, T. 2004. Plantation activities and ecosystem conservation: criteria and indicators for biodiversity conservation. In Okuda, PP. 157-160.T. and Matsumoto, Y.(eds.). Kyoto mechanism and the conservation of tropical forest ecosystem: proceedings of the International Symposium/Workshop on the Kyoto Mechanism and the Conservation of Tropical Forest Ecosystem. Tokyo, Japan. ISBN 4990-1797-3-0

Webb, D.B., Wood, p. J., Smith, J.P.,Henman, G.S. 1984. A guide to species selection for tropical and subtropical plantations. University of Oxford, Commonwealth Forestry Institute, Oxford. 256pp.

Wilson, R.A. 1992. Eucalyptus. Paradigm and protagonist (the CEASA model). Paper presented at the 2nd Market Pulp Conference, Vancouver.

Yaron, G. 1998. Alternative land use options in the Mount Cameroon Region: An economic analysis. A report prepared for the Mount Cameroon Project and Department for International Development, NRI, Chatham, UK. 


\section{Appendix 1}

Plant species richness recorded in plantation forests of the four timber species. Species richness recorded in a natural forest (NF) situated in close proximity to the plantations are also given for comparison.

\begin{tabular}{|c|c|c|c|c|c|c|c|c|}
\hline \multirow[b]{2}{*}{ Species } & \multicolumn{2}{|c|}{ Teak } & \multicolumn{2}{|c|}{ Mahogany } & \multicolumn{2}{|c|}{ E. microcorys } & \multicolumn{2}{|c|}{ E. grandis } \\
\hline & $\mathrm{P}$ & NF & $\mathrm{P}$ & $\mathrm{NF}$ & $\mathrm{P}$ & $\mathrm{NF}$ & $\mathrm{P}$ & $\mathrm{NF}$ \\
\hline Acacia caesia & & & & $\sqrt{ }$ & & & & \\
\hline Acronychia pedunculata & $\sqrt{ }$ & & $\sqrt{ }$ & $\sqrt{ }$ & & & & \\
\hline Actinodaphne speciosa & & & $\sqrt{ }$ & & & & & $\sqrt{ }$ \\
\hline Adenanthera pavonia & & & & & & & & \\
\hline Adinandra lasiopetala & & & & & & $\sqrt{ }$ & & \\
\hline Allophylus varians & & & & & $\sqrt{ }$ & $\sqrt{ }$ & & \\
\hline Alseodaphne semecarpifolia & $\sqrt{ }$ & $\sqrt{ }$ & & & & & & \\
\hline Alstonia scholaris & & & & $\sqrt{ }$ & & & & \\
\hline Andidesma alexiteria & & & & $\sqrt{ }$ & & & & \\
\hline Ardiisa humilis & $\sqrt{ }$ & $\sqrt{ }$ & $\sqrt{ }$ & $\sqrt{ }$ & & & & \\
\hline Ardisia missionis & $\sqrt{ }$ & $\sqrt{ }$ & $\sqrt{ }$ & & & & & \\
\hline Artocarpus heterophyllus & & & & $\sqrt{ }$ & & & & \\
\hline Artocarpus nobilis & & $\sqrt{ }$ & $\sqrt{ }$ & & & & & \\
\hline Arundinaria debilis & & & & & $\sqrt{ }$ & $\sqrt{ }$ & & \\
\hline Asparagas falcatus & $\sqrt{ }$ & $\sqrt{ }$ & & $\sqrt{ }$ & & & & \\
\hline Atalantia ceylanica & & & $\sqrt{ }$ & $\sqrt{ }$ & & & & \\
\hline Berberis ceylanica & & & $\sqrt{ }$ & & & & $\sqrt{ }$ & $\sqrt{ }$ \\
\hline Bhesa ceylanica & $\sqrt{ }$ & $\sqrt{ }$ & & & & & & \\
\hline Bridelia moonii & & & & $\sqrt{ }$ & & & & \\
\hline Callophyllum sp. & & & & $\sqrt{ }$ & & & & \\
\hline Callophylum walkeri & & & $\sqrt{ }$ & & $\sqrt{ }$ & $\sqrt{ }$ & $\sqrt{ }$ & $\sqrt{ }$ \\
\hline Canthium dicoccum & $\sqrt{ }$ & $\sqrt{ }$ & & & & & & \\
\hline Carallia brachiata & & & & $\sqrt{ }$ & & & & \\
\hline Caryota urens & & & $\sqrt{ }$ & $\sqrt{ }$ & & & & \\
\hline Casearia thwaitesii & & & $\sqrt{ }$ & & & $\sqrt{ }$ & & \\
\hline Celtis timorensis & & & & & & $\sqrt{ }$ & & \\
\hline Chloroxylon swietenia & & & & $\sqrt{ }$ & & & & \\
\hline Cinnamomum ovalifolium & & & $\sqrt{ }$ & & $\sqrt{ }$ & $\sqrt{ }$ & $\sqrt{ }$ & $\sqrt{ }$ \\
\hline Cinnamomum zeylanica & $\sqrt{ }$ & $\sqrt{ }$ & & $\sqrt{ }$ & & & & \\
\hline Cinnamomum cappara coronde & & & $\sqrt{ }$ & & $\sqrt{ }$ & $\sqrt{ }$ & & \\
\hline Clerodendrum inerme & & & & $\sqrt{ }$ & & & & \\
\hline Connarus monocarpus & $\sqrt{ }$ & $\sqrt{ }$ & $\sqrt{ }$ & & & & & \\
\hline Croton laccifer & & $\sqrt{ }$ & & & & & & \\
\hline Cryptocarya wightiana & & $\sqrt{ }$ & & & & & & \\
\hline Delonix regia & & & & $\sqrt{ }$ & & & & \\
\hline Demos elegans & & & $\sqrt{ }$ & $\sqrt{ }$ & & & & \\
\hline Dillenia retusa & $\sqrt{ }$ & $\sqrt{ }$ & $\sqrt{ }$ & $\sqrt{ }$ & & & & \\
\hline Diospyros racemosa & $\sqrt{ }$ & $\sqrt{ }$ & $\sqrt{ }$ & & & & & \\
\hline Diospyros walkeri & $\sqrt{ }$ & $\sqrt{ }$ & & & & & & \\
\hline Dipterocarpus zeylanicus & & & & $\sqrt{ }$ & & & & \\
\hline Elaeagnus latifolia & & & $\sqrt{ }$ & & $\sqrt{ }$ & $\sqrt{ }$ & & \\
\hline Elaecarpus glandulifer & & & & & $\sqrt{ }$ & $\sqrt{ }$ & & \\
\hline Elaeocarpus serratus & & & & $\sqrt{ }$ & & & & \\
\hline
\end{tabular}




\begin{tabular}{|c|c|c|c|c|c|c|c|c|}
\hline \multirow[t]{2}{*}{ Species } & \multicolumn{2}{|c|}{ Teak } & \multicolumn{2}{|c|}{ Mahogany } & \multicolumn{2}{|c|}{ E. microcorys } & \multicolumn{2}{|c|}{ E. grandis } \\
\hline & $\mathrm{P}$ & $\mathrm{NF}$ & $\mathrm{P}$ & NF & $\mathrm{P}$ & NF & $\mathrm{P}$ & NF \\
\hline Elaeocarpus subvillosus & & & $\sqrt{ }$ & $\sqrt{ }$ & & & & \\
\hline Eugenia rorundata & $\sqrt{ }$ & $\sqrt{ }$ & $\sqrt{ }$ & & & & & \\
\hline Euphobia decipiens & & & & & & & $\sqrt{ }$ & $\sqrt{ }$ \\
\hline Euphobia longana & $\sqrt{ }$ & $\sqrt{ }$ & & $\sqrt{ }$ & & & & \\
\hline Eurga nitida & & & $\sqrt{ }$ & & & $\sqrt{ }$ & & \\
\hline Eurya chinensis & & & & & & & $\sqrt{ }$ & $\sqrt{ }$ \\
\hline Ficus exasperata & & & & $\sqrt{ }$ & & & & \\
\hline Ficus microcarpa & & & $\sqrt{ }$ & & & & $\sqrt{ }$ & $\sqrt{ }$ \\
\hline Filicium decipiens & & & & $\sqrt{ }$ & & & & \\
\hline Gaertnera vaginans & $\sqrt{ }$ & $\sqrt{ }$ & $\sqrt{ }$ & & & & & \\
\hline Garcinia cambogia & & & & $\sqrt{ }$ & & & & \\
\hline Garcinia morella & & & & $\sqrt{ }$ & & & & \\
\hline Garcinia spicata & $\sqrt{ }$ & $\sqrt{ }$ & $\sqrt{ }$ & & & & & \\
\hline Glochidion pycnocarpum & & & & & $\sqrt{ }$ & $\sqrt{ }$ & $\sqrt{ }$ & $\sqrt{ }$ \\
\hline Glycosmis angustifolia & & & & $\sqrt{ }$ & & & & \\
\hline Goniothalamus gardenari & $\sqrt{ }$ & $\sqrt{ }$ & $\sqrt{ }$ & & & & & \\
\hline Gymneme laciferum & & $\sqrt{ }$ & & & & & & \\
\hline Gyrinops walla & $\sqrt{ }$ & $\sqrt{ }$ & & & & & & \\
\hline Hedyotis dendroides & & & & & & $\sqrt{ }$ & & \\
\hline Hedyotis flavescens & & & & & & $\sqrt{ }$ & & \\
\hline Hedyotis gartmorensis & & & & & & & $\sqrt{ }$ & $\sqrt{ }$ \\
\hline Hedyotis trimenii & & & & & & $\sqrt{ }$ & & \\
\hline Holarrhena mitis & $\sqrt{ }$ & $\sqrt{ }$ & & & & & & \\
\hline Humboldtia laurifolia & $\sqrt{ }$ & $\sqrt{ }$ & & & & & & \\
\hline Hunteria zeylanica & $\sqrt{ }$ & $\sqrt{ }$ & & & & & & \\
\hline Ilex walker & & & & & & & $\sqrt{ }$ & $\sqrt{ }$ \\
\hline Isonandra compts & $\sqrt{ }$ & $\sqrt{ }$ & & & & & & \\
\hline Ixora sp. & & & & $\sqrt{ }$ & & & & \\
\hline Lasianthus oliganthus & & & $\sqrt{ }$ & & & $\sqrt{ }$ & & \\
\hline Litsea glutinosa & & & & $\sqrt{ }$ & & & & \\
\hline Litsea ovalifolia & & & $\sqrt{ }$ & & & & $\sqrt{ }$ & $\sqrt{ }$ \\
\hline Mallotus albus & & & & $\sqrt{ }$ & & & & \\
\hline Mallotus philippensis & & & $\sqrt{ }$ & $\sqrt{ }$ & & & & \\
\hline Mangifera indica & & & $\sqrt{ }$ & $\sqrt{ }$ & & & & \\
\hline Mangifera zeylanica & $\sqrt{ }$ & $\sqrt{ }$ & $\sqrt{ }$ & & & & & \\
\hline Mastinia montana & & & & & & $\sqrt{ }$ & & \\
\hline Mastixia simplicifolia & & & & & & & $\sqrt{ }$ & $\sqrt{ }$ \\
\hline Measa indica & & & & & & & & $\sqrt{ }$ \\
\hline Meliosma pinnata & & & & & $\sqrt{ }$ & $\sqrt{ }$ & & \\
\hline Meliosma simplicifolia & & & & & & $\sqrt{ }$ & & \\
\hline Memecylon gracillium & $\sqrt{ }$ & $\sqrt{ }$ & & & & & & \\
\hline Memecylon rostratum & & $\sqrt{ }$ & & & & & & \\
\hline Miclulia nilagirica & & & & & & $\sqrt{ }$ & & \\
\hline Microtropis zeylanica & & & & & & $\sqrt{ }$ & & \\
\hline Morinda citrifolia & & & & $\sqrt{ }$ & & & & \\
\hline Myristica ceylanica & $\sqrt{ }$ & $\sqrt{ }$ & $\sqrt{ }$ & & & & & \\
\hline Neolitsea cassia & & & & $\sqrt{ }$ & & & & \\
\hline Neolitsea fuscata & & & $\sqrt{ }$ & & & & $\sqrt{ }$ & $\sqrt{ }$ \\
\hline
\end{tabular}




\begin{tabular}{|c|c|c|c|c|c|c|c|c|}
\hline \multirow[b]{2}{*}{ Species } & \multicolumn{2}{|c|}{ Teak } & \multicolumn{2}{|c|}{ Mahogany } & \multicolumn{2}{|c|}{ E. microcorys } & \multicolumn{2}{|c|}{ E. grandis } \\
\hline & $\mathrm{P}$ & $\mathrm{NF}$ & $\mathrm{P}$ & $\mathrm{NF}$ & $\mathrm{P}$ & $\mathrm{NF}$ & $\mathrm{P}$ & NF \\
\hline Nothapodytes nimmoniana & & & & & & $\sqrt{ }$ & & \\
\hline Nothopegia beddomei & & & & $\sqrt{ }$ & & & & \\
\hline Pagiantha dichotoma & & & $\sqrt{ }$ & $\sqrt{ }$ & & & & \\
\hline Piper sp. & & & $\sqrt{ }$ & & & & $\sqrt{ }$ & $\sqrt{ }$ \\
\hline Piper sylvestre & & & & $\sqrt{ }$ & & & & \\
\hline Piper zeylanicum & & & $\sqrt{ }$ & $\sqrt{ }$ & $\sqrt{ }$ & $\sqrt{ }$ & & \\
\hline Polyalthia korinti & $\sqrt{ }$ & $\sqrt{ }$ & & & & & & \\
\hline Pometia pinnata & $\sqrt{ }$ & $\sqrt{ }$ & & & & & & \\
\hline Psychotria zeylanica & & & & & & $\sqrt{ }$ & & \\
\hline Rhododendron arboretum & & & & & & & $\sqrt{ }$ & $\sqrt{ }$ \\
\hline Rourea minor & $\sqrt{ }$ & $\sqrt{ }$ & & & & & & \\
\hline Rubus ellipticus & & & & & & & & $\sqrt{ }$ \\
\hline Salacia reticulata & $\sqrt{ }$ & $\sqrt{ }$ & & & & & & \\
\hline Salacia reticulata & & & & & $\sqrt{ }$ & & & \\
\hline Salmalia insignis & & & $\sqrt{ }$ & $\sqrt{ }$ & $\sqrt{ }$ & & & \\
\hline Sarcococca brevifolia & & & $\sqrt{ }$ & $\sqrt{ }$ & & & $\sqrt{ }$ & $\sqrt{ }$ \\
\hline Sarcococca zeylanica & & & & & $\sqrt{ }$ & $\sqrt{ }$ & & \\
\hline Sarcococca zeylanica & & & & & & & $\sqrt{ }$ & $\sqrt{ }$ \\
\hline Scyphostachys coffaeoides & & & & & $\sqrt{ }$ & & & \\
\hline Semecarpus coriacea & & & & $\sqrt{ }$ & & $\sqrt{ }$ & & \\
\hline Semecarpus coriacea & & & & & $\sqrt{ }$ & & & \\
\hline Smilax sp. & & & & & & & $\sqrt{ }$ & $\sqrt{ }$ \\
\hline Smilax zeylanica & & & & & $\sqrt{ }$ & $\sqrt{ }$ & & \\
\hline Smilax zeylanica & & & & & & & & \\
\hline Strebius taxoides & $\sqrt{ }$ & $\sqrt{ }$ & & & & & & \\
\hline Swietenia macrophylla & & & & & $\sqrt{ }$ & & & \\
\hline Symplocos cochinchinensis & & & & $\sqrt{ }$ & $\sqrt{ }$ & $\sqrt{ }$ & $\sqrt{ }$ & $\sqrt{ }$ \\
\hline Symplocos cordifolia & & & & & & $\sqrt{ }$ & & \\
\hline Symplocos elegans & & & & & & & $\sqrt{ }$ & $\sqrt{ }$ \\
\hline Symplocos obtuse & & & & & & & $\sqrt{ }$ & $\sqrt{ }$ \\
\hline Sysygium revolutum & & & & & $\sqrt{ }$ & $\sqrt{ }$ & $\sqrt{ }$ & $\sqrt{ }$ \\
\hline Syzygium rotundifolium & & & & & & & $\sqrt{ }$ & $\sqrt{ }$ \\
\hline Syzygium umbrosum & & & & & & & & $\sqrt{ }$ \\
\hline Tarenna flava & & & & & $\sqrt{ }$ & $\sqrt{ }$ & & \\
\hline Tectona grandis & & & & & $\sqrt{ }$ & & & \\
\hline Terminalia bellirica & & & $\sqrt{ }$ & & $\sqrt{ }$ & & & \\
\hline Toddalia asiatica & & & & $\sqrt{ }$ & $\sqrt{ }$ & $\sqrt{ }$ & & \\
\hline Turpinia malabarica & & & & & & $\sqrt{ }$ & & \\
\hline Uncara elliptica & $\sqrt{ }$ & $\sqrt{ }$ & & & & & & \\
\hline Vaccinium symplocifolium & & & & & & $\sqrt{ }$ & & \\
\hline Vitex altissima & & & & & $\sqrt{ }$ & & & \\
\hline
\end{tabular}




\section{Appendix 2}

Avifaunal species richness in the three forest plantations of the four timber species recorded during the present study. The species of birds recorded in the adjacent natural forests have also been provided for comparison.

\begin{tabular}{|c|c|c|c|c|c|c|c|c|}
\hline \multirow[b]{2}{*}{ Birds } & \multicolumn{2}{|c|}{ Teak } & \multicolumn{2}{|c|}{ Mahogany } & \multicolumn{2}{|c|}{ E.microcorys } & \multicolumn{2}{|c|}{ E.grandis } \\
\hline & $\mathrm{P}$ & NF & $\mathrm{P}$ & $\mathrm{NF}$ & $\mathrm{P}$ & $\mathrm{NF}$ & $\mathrm{P}$ & NF \\
\hline Accipiter badius & & & $\sqrt{ }$ & $\sqrt{ }$ & & & $\sqrt{ }$ & \\
\hline Acridotheres tristis & & & & & & & & $\sqrt{ }$ \\
\hline Anthracoceros coronatus & & & $\sqrt{ }$ & $\sqrt{ }$ & & & & \\
\hline Apus affinis & & & $\sqrt{ }$ & $\sqrt{ }$ & & & $\sqrt{ }$ & $\sqrt{ }$ \\
\hline Bradypterus Palliser $*_{i}$ & & & & & & & & $\sqrt{ }$ \\
\hline Cacomantis sonneratii & & & & $\sqrt{ }$ & & & $\sqrt{ }$ & $\sqrt{ }$ \\
\hline Centropus sinensis & & & & & & & & $\sqrt{ }$ \\
\hline Chalcophaps indica & & & $\sqrt{ }$ & $\sqrt{ }$ & & & & \\
\hline Collocalia unicolor & & & $\sqrt{ }$ & $\sqrt{ }$ & $\sqrt{ }$ & $\sqrt{ }$ & & \\
\hline Copsychus malabaricus & $\sqrt{ }$ & $\sqrt{ }$ & $\sqrt{ }$ & $\sqrt{ }$ & & & & \\
\hline Coracina macei & & & $\sqrt{ }$ & $\sqrt{ }$ & & & $\sqrt{ }$ & \\
\hline Corvus macrorhynchos & & & & & & & & $\sqrt{ }$ \\
\hline Culicicapa ceylonensis & & & & & & $\sqrt{ }$ & & \\
\hline Cyornis tickelliae & $\sqrt{ }$ & $\sqrt{ }$ & $\sqrt{ }$ & $\sqrt{ }$ & & & & \\
\hline Dicaeum erythrorynchos & & & & & & & & $\sqrt{ }$ \\
\hline Dicrurus macrocercus & & & $\sqrt{ }$ & $\sqrt{ }$ & & & $\sqrt{ }$ & \\
\hline Dinopium benghalense & & & & $\sqrt{ }$ & & & & \\
\hline Gallas lafayetii * & & & & & $\sqrt{ }$ & $\sqrt{ }$ & $\sqrt{ }$ & $\sqrt{ }$ \\
\hline Hemiprocne coronate & $\sqrt{ }$ & $\sqrt{ }$ & $\sqrt{ }$ & $\sqrt{ }$ & & & & \\
\hline Hemipus picatus & & $\sqrt{ }$ & $\sqrt{ }$ & $\sqrt{ }$ & & & & \\
\hline Hirundo daurica & & & $\sqrt{ }$ & $\sqrt{ }$ & & & & \\
\hline Hypothymis azurea & & & $\sqrt{ }$ & $\sqrt{ }$ & & & & \\
\hline Hypsipetes leucocephalus & & & & & & & & $\sqrt{ }$ \\
\hline Pycnonotus cafer & & & & & & & & $\sqrt{ }$ \\
\hline Lonchura kelaarti & & & & & & & & $\sqrt{ }$ \\
\hline Megalaima flavifrons $*$ & & & & & & $\sqrt{ }$ & & \\
\hline Megalaima haemacephala & $\sqrt{ }$ & $\sqrt{ }$ & & & & $\sqrt{ }$ & & \\
\hline Megalaima rubricapilla & $\sqrt{ }$ & $\sqrt{ }$ & $\sqrt{ }$ & $\sqrt{ }$ & & & & \\
\hline Muscicapa latirostris & $\sqrt{ }$ & $\sqrt{ }$ & & $\sqrt{ }$ & $\sqrt{ }$ & $\sqrt{ }$ & $\sqrt{ }$ & $\sqrt{ }$ \\
\hline Muscicapa sordid & & & & & & & & $\sqrt{ }$ \\
\hline Nectarinia asiatica & & $\sqrt{ }$ & $\sqrt{ }$ & $\sqrt{ }$ & & & & \\
\hline Ocyceros gingalensis * & $\sqrt{ }$ & $\sqrt{ }$ & $\sqrt{ }$ & $\sqrt{ }$ & & & & \\
\hline Oriolus xanthornus & & & & $\sqrt{ }$ & & & & \\
\hline Orthotomus sutorius & & & & & & $\sqrt{ }$ & & \\
\hline Phylloscopus magnirostris & & $\sqrt{ }$ & $\sqrt{ }$ & $\sqrt{ }$ & & & & \\
\hline Pomatorhinus horsfieldii & & & & & & $\sqrt{ }$ & & \\
\hline Pycnonotus melanicterus & & $\sqrt{ }$ & & $\sqrt{ }$ & & & & \\
\hline Pycnonotus penicillatus & & & & & $\sqrt{ }$ & $\sqrt{ }$ & $\sqrt{ }$ & $\sqrt{ }$ \\
\hline Rhopocichla atriceps & & & & & & $\sqrt{ }$ & & $\sqrt{ }$ \\
\hline Sitta frontalis & & & $\sqrt{ }$ & $\sqrt{ }$ & $\sqrt{ }$ & $\sqrt{ }$ & $\sqrt{ }$ & \\
\hline Turdus merula & & & & & & & & $\sqrt{ }$ \\
\hline Turdoides rufescens * & & & & & & & & $\sqrt{ }$ \\
\hline Zoothera spiloptera * & & & & & $\sqrt{ }$ & $\sqrt{ }$ & $\sqrt{ }$ & \\
\hline Zosterops ceylonensis * & & & & & & $\sqrt{ }$ & & $\sqrt{ }$ \\
\hline
\end{tabular}

